\title{
MENINGKATKAN PEMAHAMAN KONSEP ASESMEN MELALUI PROSES MIND MAPPING
}

\author{
Siti Rohmi Yuliati
}

\begin{abstract}
ABSTRAK
The students of Primary Education Teachers Education of S1 in the Scool of Education, State University of Jakarta, found difficulties in understanding and implementing of assessment concept in the course of Instructional Evaluation Development. This classroom action research which was conducted in 2008, aimed at overcoming the difficulties by using mind mapping startegy. Involving 70 students of Primary Teachers Education in theShcool of Education of State University of Jakarta, the research employed developing and improving instructional quality method following the classroom action research model introduced by Standford and Kemmis. At the end of the research it wa sfound out there ia a significant improvement of the students' understanding in the assessment concept.
\end{abstract}

Key words: assessment concept, mind mapping strategy, classroom action research.

\section{PENDAHULUAN}

Banyak hal yang dapat mempengaruhi tingkat kualitas pembelajaran yang dilaksanakan oleh suatu institusi karena adanya keterbatasan, misalnya kualitas SDM dari para pengajar yang masih terbawa pada sistem lama. Sistem yang dimaksud adalah hanya mengacu pada konten dari satu buku ajar tanpa memperbaharui dan menambah referensi dari sumber lain.

Rendahnya tingkat pemahaman para mahasiswa S1 PGSD UNJ pada mata kuliah pengembangan evaluasi pembelajaran, ditunjukkan dengan kecilnya nilai yang dicapai pada setiap akhir semester selama ini. Mahasiswa yang memiliki nilai C berkisar $70 \%$ dari jumlah mahasiswa di setiap kelas (6 kelas). Sedangkan kurangnya pemahaman mahasiswa terhadap konsep penilaian ditandai dengan ketidaktahuan mereka menentukan jenis penilaian apa yang akan dipilih setiap kali membuat rancangan pembelajaran mata kuliah. Para mahasiswa hanya tahu bahwa penilaian adalah tes, padahal masih banyak jenis penilaian lain yang sesuai dengan materi ajar.

Mata kuliah Pengembangan Evaluasi Pembelajaran merupakan salah satu mata kuliah pada program S1 PGSD yang materinya membahas tentang bagaimana menentukan jenis dan teknik penilaian yang akan dilaksanakan oleh seorang guru sekolah dasar (SD) pada setiap mata pelajaran.

Seorang guru seharusnya dapat melaksanakan beragam jenis penilaian sesuai dengan materi, seperti pengamatan kinerja, pengukuran sikap, penilaian hasil karya berupa tugas, penilaian proyek, penilaian produk, penilaian portofolio, dan penilaian diri sendiri. Penilaian dilakukan minimal satu kali dalam satu semester. Jenis-jenis penilaian tersebut dapat menggunakan teknik-teknik tertulis, observasi, tes praktik, penugasan, tes lisan, portofolio, jurnal, inventori, penilaian diri sendiri, dan penilaian antarteman.

Untuk mengatasi rendahnya pemahaman mahasiswa tersebut, perlu suatu strategi khusus yang harus dilakukan oleh dosen pengampu mata kuliah Pengembangan Evaluasi Pembelajaran dengan menggunakan strategi pembelajaran yang baru yaitu mind mapping.

Peneliti berusaha untuk meningkatkan pemahaman konsep mahasiswa S1 PGSD FIP UNJ terhadap pemilihan model penilaian yang ada melalui proses mind mapping yang dikembangkan dari indikator yang dalam penelitian ini. Penelitian ini hanya dibatasi pada cara meningkatkan pemahaman konsep asesmen Mahasiswa PGSD FIP UNJ melalui proses mind mapping pada mata pelajaran Matematika SD. Rumusan masalah dalam penelitian ini adalah: Bagaimana cara meningkatkan pemahaman konsep asesmen Mahasiswa PGSD FIP UNJ melalui strategi belajar mind mapping pada mata kuliah pengembangan evaluasi pembelajaran?

\section{KAJIAN TEORETIS}

\section{Hakikat Pemahaman Konsep}

Menurut I. Gusti Oka (1983:17), pemahaman berarti mampu menyelami pikiran orang lain dan menambahkan pemikiran serta pengalaman orang lain ke dalam pemikiran dan pengalaman kita sendiri. Sujana (1998:24) mengkategorikan pemahaman, 
sebagai berikut.

(1) Pemahaman terendah, yaitu pemahaman terjemahan, mulai dari terjemahan dalam arti sebenarnya.

(2) Pemahaman penafsiran, yaitu menghubungkan bagian-bagian terdahulu dengan yang diketahui berikutnya atau menghubungkan beberapa dari grafik dengan kejadian membedakan yang pokok dan yang bukan pokok.

(3) Pemahaman tertinggi, yaitu pemahaman ekstrapolasi, yang memungkinkan seseorang mampu melihat di balik yang tertulis, dapat membuat ramalan tentang konsekuensi atau dapat memperluas persepsi dalam arti waktu, dimensi, kasus atau masalahnya.

Sedangkan Bloom dalam Usman (2003:112) mendefinisikan pemahaman sebagai kemampuan untuk menyerap arti dan materi atau bahan yang dipelajari. Ini dapat ditunjukkan dengan menterjemahkan materi dari satu bentuk kebentuk yang lain (dari angka kepada angka-angka), menginterpretasikan materi (menjelaskan, meringkas atau meramalkan akibat dari sesuatu).

Beberapa pengertian di atas menunjukkan bahwa pemahaman adalah kemampuan seseorang untuk dapat mengerti akan sesuatu dan dengan pengertian yang didapatnya serta menggunakan keterampilan lain dapat memecahkan masalah yang terkait dengan pengertian tersebut. Siswa dikatakan paham bila ia mengetahui apa yang terkandung dalam konsep yang dipelajari dan dapat dengan mandiri menyelesaikan permasalahan yang berhubungan dengan konsep tersebut. Selain itu, siswa yang paham akan dengan mudah menyebutkan, menjelaskan kembali pengetahuan atau konsep yang di dapat dengan kata-katanya sendiri.

Suherman (2003: 33) mendefinisikan konsep sebagai ide abstrak yang memungkinkan kita dapat mengelompokkan objek ke dalam contoh dan noncontoh. Konsep adalah suatu ide atau persepsi mental. Digunakan kata-kata atau simbol digunakan untuk mendeskripsikan atau memberi label konsep tersebut.

\section{Pengertian Asesmen/Penilaian}

Penilaian adalah proses penyusunan deskripsi siswa, baik secara langsung di kelas maupun di luar kelas berupa serangkaian kegiatan untuk memperoleh, menganalisis, dan menafsirkan data tentang proses dan hasil peserta didik yang dilakukan secara sistematis dan berkesinambungan, sehingga menjadi informasi yang bermakna dalam pengambilan keputusan. Untuk itu, istilah penilaian akan lebih tepat diganti dengan asesmen. Jika penilaian lebih ditekankan pada hasilnya saja, maka asesmen lebih menekankan pada prosesnya.

Asesmen merupakan salah satu kegiatan dari 'lingkaran belajar mengajar', seperti yang dapat dilihat dari gambar berikut ini.

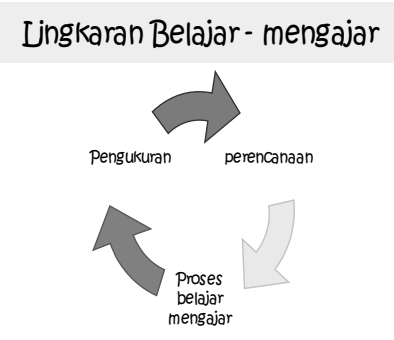

\section{Gambar 1. Lingkaran belajar mengajar}

Untuk mendapatkan hasil yang diharapkan diperlukan suatu sistem penilaian yang sesuai, baik dengan komponen penilaian maupun dengan tujuantujuan pembelajaran yang telah ditentukan sebelumnya. Sejumlah informasi yang diperoleh melalui evaluasi pembelajaran kemudian difungsikan dan ditujukan untuk pengembangan pembelajaran (Dimyati dan Mujiono, 2000:221).

Pelaksanaan penilaian selama ini cenderung hanya bersifat kuantitatif dan terfokus hamya pada aspek kognitif saja. Padahal menurut Gronlund (1993: 3), terdapat beberapa tipe penilaian, yaitu 1) penilaian pada awal pembelajaran, 2) penilaian pada saat berlangsungnya pembelajaran, 3) penilaian pada akhir pembelajaran, dan 4) penilaian yang dapat membantu memotivasi siswa, menolong mentransfer materi pelajaran, membantu siswa mengevaluasi diri sendiri dan membantu siswa dalam pengevaluasian keefektifan instruksional.

Penilaian hendaknya selalu berorientasi pada proses dan produk, bahkan penilaian bukan suatu prestasi yang hanya sesaat, tapi lebih pada penampilan yang dipantau secara terus menerus. Penilaian pencapaian kompetensi dasar peserta didik dilakukan berdasakan indikator, dapat berjenis tes dan nontes, dan berbentuk tertulis maupun lisan, yang harus pernah dilakukan minimal satu kali dari oleh seorang pengajar semua jenis penilaian, yaitu pengamatan kinerja, pengukuran sikap, penilaian hasil karya berupa tugas, penilaian proyek, penilaian produk, penilaian portofolio, dan penilaian diri sendiri.

Hal-hal yang perlu dperhatikan dalam pelaksanaan penilaian seperti disebutkan dalam standart isi pada kurikulum 2006 dari kurikulum tingkat satuan pendidikan (KTSP) adalah 1) penilaian diarahkan untuk mengukur pencapaian kompetensi, 2) penilaian menggunakan acuan kriteria, 3) penilaian 
menggunakan sistem berkelanjutan, 4) hasil penilaian dianalisis untuk menentukan tindak lanjut, dan 5) sistem penilaian harus disesuaikan dengan pengalaman belajar yang ditempuh dalam proses pembelajaran.

Dari uraian di atas, dapat diketahui bahwa yang dimaksud dengan pemahaman konsep asesmen adalah kemampuan seseorang untuk dapat mengerti dan menggunakan keterampilan dalam memecahkan masalah penilaian. Masalah tersebut berhubungan dengan pengertian penilaian yang masih bersifat abstrak, kemudian dikonkretkan dan dideskripsikan melalui simbolisasi serta menjadi dasar untuk menguasai dan menerapkan jenis-jenis penilaian pada saat mengajar.

\section{Hakikat Strategi Belajar Mind Mapping}

Buzan (2006:16) menyatakan bahwa strategi mind mapping merupakan cara yang paling mudah untuk memasukkan informasi ke dalam otak dan untuk mengambil informasi dari otak. Cara ini adalah cara yang paling kreatif dan efektif dalam membuat catatan sehingga boleh dikatakan mind mapping benar-benar memetakan pikiran orang yang membuatnya.

Mind mapping dibuat dengan kata-kata, warna, garis, dan gambar. Mind mapping bisa menolong kita untuk lebih baik dalam mengingat, mendapatkan ide brilian, berkonsentrasi, menghemat waktu dan memanfaatkan waktu yang kita miliki dengan sebaik-baiknya, serta mendapatkan nilai bagus. Dalam mind mapping, siswa akan membuat catatan menggunakan kedua keahlian otak kiri dan otak kanan. Karena selain membuat catatan dengan kata-kata, mind map mengajak otak kita berpikir dalam bentuk gambar dan warna, yang lebih ramah-otak.

Mind mapping yang menurut Fauziah (2005:1), dari Konsorsium pendidikan Islam (KPI) adalah metode merangkum yang sesuai dengan kerja otak. Sedangkan Emil (2007:1) menambahkan bahwa strategi mind mapping dapat membantu pebelajar lebih mudah menyerap pelajaran. Dengan strategi mind mapping, diharapkan mahasiswa dapat mengembangkan kemampuan berpikir dan bernalarnya, sehingga dengan mudah akan dapat pula mengembangkan alur berfikirnya dan membantu siswa lebih mudah menyerap pelajaran.

Pengertian mind mapping menurut Wikipedia (2007 adalah "A mind map is a diagram used to represent words, ideas, tasks or other items linked to and arranged radially around a central key word or idea. It is used to generate, visualize, structure and classify ideas, and as an aid in study, organization, problem solving, decision making, and writing".
Peta pikiran adalah merupakan diagram yang digunakan untuk menampilkan kata-kata, gagasan, tugas atau materi lain yang dapat mengungkapkan suatu gagasan atau kata kunci dari sebuah konsep. Kata kunci itu digunakan untuk menghasilkan ide, mengkhayalkan konsep, struktur dan menggolongkan gagasan, dan sebagai sesuatu yang membantu studi, organisasi, pemecahan masalah, pengambilan keputusan, dan menuliskan konsep.

Beberapa penelitian menunjukkan bahwa strategi belajar mind mapping menghasilkan peningkatan hasil belajar dan kualitas pembelajaran lebih baik dibandingkan dengan metode konvensional. Contohnya adalah penelitian Amaliah (2005-2006:10) yang menghasilkan suatu kesimpulan bahwa ada perbedaan yang signifikan antara kelas yang menggunakan strategi mind mapping dengan yang menggunakan model konvensional. Sedangkan hasil penelitian Rosia dan Awit Marini adalah siswa mengalami peningkatan dalam menulis karangan setelah dilakukan strategi belajar mind mapping.

Tahapan pelaksanaan pembelajaran mind mapping menurut (Arends 1997:15) dalam Mujito (2008:46) adalah sebagai berikut, tahap pertama menyampaikan tujuan pembelajaran dan memotivasi siswa. Tahap kedua, secara klasikal menjelaskan strategi menggarisbawahi dan pemetaan konsep dan memodelkan strategi mengarisbawahi dan membuat peta konsep. Tahap ketiga, melatih siswa menggunakan strategi menggarisbawahi dan pemetaan konsep di bawah bimbingan guru. Tahap keempat, memeriksa pemahaman siswa terhadap strategi menggarisbawahi dan pemetaan konsep dan memberi umpan balik hasil pemahaman siswa terhadap strategi menggarisbawahi dan pemetaan konsep. Tahap kelima, melatih siswa untuk menerapkan strategi belajar menggarisbawahi dan membuat peta konsep secara mandiri. Tahap keenam, mengevaluasi tugas latihan menggarisbawahi dan membuat peta konsep dan membimbing siswa untuk merangkum pelajaran.

Contoh strategi mind mapping dalam pembelajaran matematika yang digambarkan sebagai berikut.

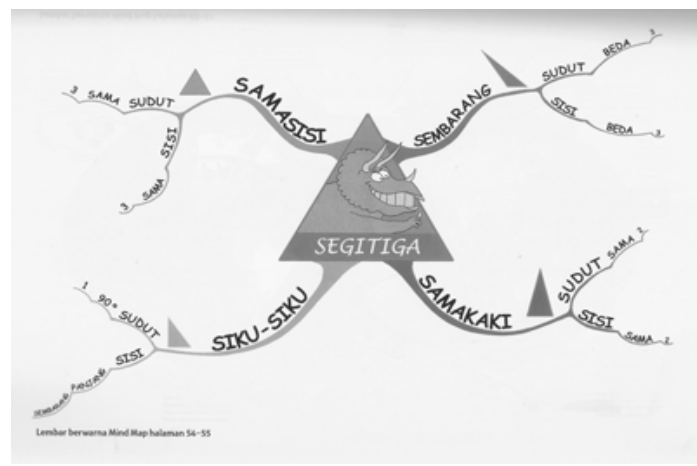


Tujuh langkah dalam membuat mind map menurut Buzan (2007: 15-16), adalah.

a. Mulailah dari bagian tengah kertas kosong yang sisi panjangnya diletakkan mendatar. Memulai dari tengah memberi kebebasan kepada otak untuk menyebar ke segala arah dan untuk mengungkapkan dirinya dengan lebih bebas dan alami.

b. Gunakan gambar atau foto untuk ide sentral anda. Sebuah gambar bermakna seribu kata dan membantu kita menggunakan imajinasi. Sebuah gambar sentral akan lebih menarik, membuat kita tetap terfokus, membantu kita berkonsentrasi, dan mengaktifkan otak.

c. Gunakan warna. Bagi otak, warna sama menarik nya dengan gambar. Warna membuat Mind Map lebih hidup, menambah energi kepada pemikiran kreatif, dan menyenangkan.

d. Hubungkan cabang-cabang utama ke gambar pusat dan hubungkan cabang-cabang tingkat dua dan tiga ketingkat satu dan dua, dan seterusnya. Otak bekerja menurut asosiasi dan senang mengaitkan dua, tiga, atau empat hal sekaligus. Bila menghubungkan cabang-cabang, orang akan lebih mudah mengingat dan mengingat. Penghubungan cabang-cabang utama akan menciptakan dan menetapkan struktur dasar atau arsitektur pikiran kita. Ini serupa dengan cara pohon mengaitkan cabang-cabangnya yang menyebar dari batang utama. Jika ada celah-celah kecil di antara batang sentral dengan cabang-cabang utama atau di antara cabang-cabang utama dengan cabang dan ranting yang lebih kecil, alam tidak akan bekerja dengan baik. Tanpa ada hubungan dalam mind map seseorang, segala sesuatu (terutama ingatan dan pembelajaran!) akan berantakan. Jadi buat hubungan!

e. Buatlah garis-garis hubungan yang melengkung, bukan garis lurus. Garis lurus akan membosankan otak. Cabang-cabang yang melengkung dan organis, seperti cabang-cabang pohon, jauh lebih menarik bagi mata.

f. Gunakan satu kata kunci untuk setiap garis. Kata kunci tunggal memberi lebih banyak daya dan fleksibilitas kepada mind map. Setiap kata tunggal atau gambar adalah seperti pengganda, menghasilkan sederet asosiasi dan hubungannya sendiri. Bila kita menggunakan kata tunggal, setiap kata ini akan lebih bebas dan karenanya lebih bisa memicu ide dan pikiran baru. Kalimat atau ungkapan cenderung menghambat efek pemicu ini. Mind map yang memiliki lebih banyak kata kunci seperti tangan yang semua sendi jarinya bekerja. Mind map yang memiliki kalimat atau ungkapan adalah seperti tangan yang semua jemarinya diikat.

g. Gunakan gambar. Seperti gambar sentral, setiap gambar bermakna seribu kata. Jadi bila kita hanya mempuyai 10 gambar di dalam mind map maka sudah setara dengan 10.000 kata catatan.

\section{Pengembangan Konseptual}

Dalam mencapai aktivitas belajar siswa yang maksimal dan berkualitas diperlukan suatu strategi dan program pembelajaran yang mengutamakan pencapaian berupa pengetahuan kognitif, afektif, dan psikomotor yang diperoleh melalui pengalaman belajar yang bermakna.

Strategi mind mapping dipandang perlu untuk diterapkan karena dapat membantu mahasiswa untuk lebih baik dalam mengingat, mendapatkan ide brilian, menghemat waktu dan memanfaatkan waktu yang dimiliki dengan sebaik-baiknya serta untuk memperoleh pemahaman yang baik terhadap pelajaran Matematika. Selain itu, strategi mind mapping melatih daya konsentrasi dan mengoptimalkan kemampuan otak kiri dan kanan. Proses pembelajaran yang menyenangkan pada akhirnya menentukan peningkatan aktivitas belajar siswa.

Dari uraian di atas dapat disimpulkan bahwa strategi mind mapping dalam pembelajaran matematika adalah metode merangkum materi sesuai dengan kerja otak yang dapat merubah sistem belajar abstrak menjadi model membangun dasar konkret pada mata pelajaran Matematika dengan proses perubahan kegiatan dan reaksi terhadap lingkungan diperoleh, yaitu objek langsung berupa aktivitas belajar baik kognitif, afektif, dan psikomotor yang dapat ditingkatkan melalui penggunaan strategi pembelajaran mind map, sehingga dapat ditujukan sebagai penentu kemajuan pengetahuan dan pendidikan dalam dunia pendidikan serta kehidupan sehari-hari, objek tak langsung berupa kemampuan menyelidiki dan memecahkan masalah, belajar mandiri, bersikap positif terhadap matematika dalam kombinasi yang tersusun meliputi unsur-unsur: manusia, materi, fasilitas, perlengkapan, dan prosedur yang saling mempengaruhi untuk mencapai tujuan yang sudah ditentukan

\section{Hipotesis Tindakan}

Hipotesis yang diajukan dalam penelitian ini dirumuskan: Strategi mind mapping dapat meningkatkan pemahaman konsep asesmen mahasiswa PGSD FIP UNJ. 
dan evaluasi yang telah dilaksanakan untuk menentukan langkah selanjutnya.

Tujuan penelitian ini adalah untuk meningkatkan pemahaman konsep asesmen Mahasiswa PGSD FIP UNJ dengan menggunakan strategi mind mapping pada perkuliahan Pengembangan Evaluasi Pembelajaran. Sedangkan metode penelitian menggunakan metode Pengembangan dan Peningkatan Kualitas Pembelajaran (PPKP) di LPTK dengan pendekatan penelitian tindakan kelas (PTK) yang mengacu pada model yang dikembangkan oleh Stanford dan Kemmis serta Burn. Model ini memiliki tujuan untuk melakukan perbaikan-perbaikan terhadap proses perkuliahan, berdaur ulang, dan dilakukan masing-masing individu dalam suatu kelompok dengan model siklus, di mana pada setiap siklusnya terdiri dari tahapan: perencanaan, pelaksanaan, observasi, dan refleksi dalam tiga siklus.

Subjek penelitian adalah peneliti sebagai dosen pengampu mata kuliah Pengembangan Evaluasi Pembelajaran dan mahasiswa S1 Alih Program kelas 203 berjumlah 40 orang. Sedangkan objek penelitian adalah pelaksanaan perkuliahan pengembangan evaluasi pembelajaran kelas 203 menggunakan proses mind mapping.

\section{Rancangan Penelitian}

Dalam tahap refleksi Awal, dosen bersama mahasiswa melakukan diskusi terhadap rancangan proses perkuliahan, sehingga menemukan masalah (seperti diuraikan pada identifikasi masalah)

Dalam tahap perencanaan dosen mengajak teman sejawat yang pengampu mata kuliah yang sama bersama mahasiswa membuat kesepakatan tentang akan diberlakukannya strategi mind mapping dalam perkuliahan, membuat rancangan perkuliahan, instrumen hasil penelitian dan pemantau tindakan, menyiapkan media rekam gambar, dan membagi kelas menjadi 6 kelompok.

Dalam tahap pelaksanaan. Perkuliahan pengembangan evaluasi pembelajaran dengan strategi mind mapping ditandai dengan kerja setiap kelompok (kelompok kelas 1 sampai kelas 6)

Dalam tahap observasi/evaluasi, observer melakukan pengamatan mengenai jalannya perkuliahan. Evaluasi dilakukan oleh dosen dan teman sejawat, untuk mengetahui tingkat pemahaman mahasiswa pada masing-masing kelompok terhadap konsep penilaian yang akan dipergunakan dan hasil penilaian dari tes yang diberikan.

Dalam tahap refleksi, mahasiswa bersama-sama dosen dan observer melakukan refleksi hasil observasi

\section{Rangkaian pelaksanaan penelitian} digambarkan, sebagai berikut.

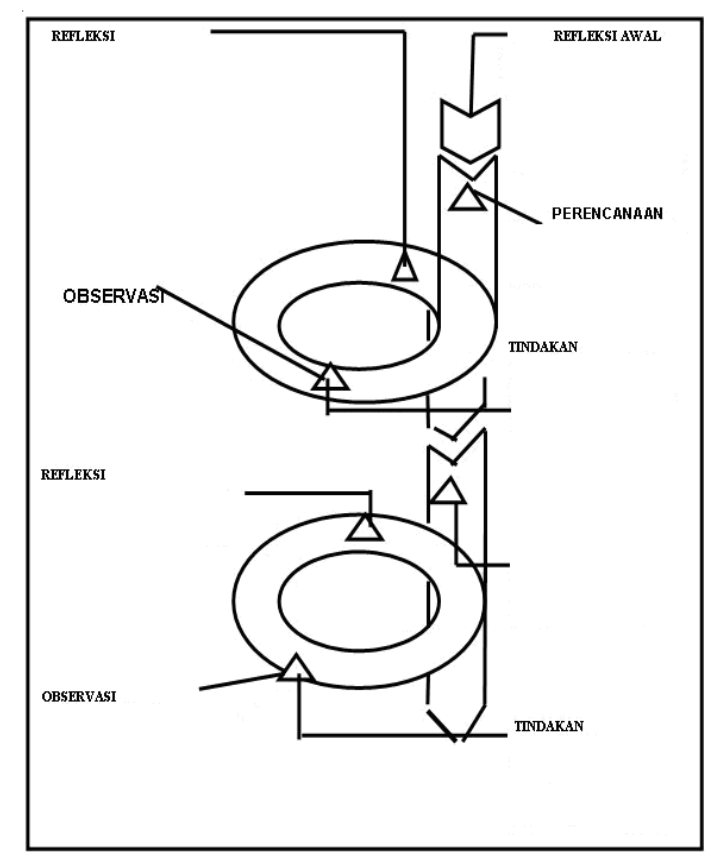

Gambar 2. Rangkaian pelaksanaan penelitian (Dimodifikasi dari Burns, 1999: 33).

Indikator Keberhasilan ditandai dengan kriteria jika minimal $80 \%$ dari jumlah mahasiswa S1 PGSD FIP UNJ Kelas 203 mandapatkan skor sekurang kurangnya 70 (B), maka Strategi mind mapping dalam perkuliahan Pengembangan Evaluasi Pembelajaran untuk Meningkatkan Pemahaman Konsep Asesmen Mahasiswa PGSD FIP UNJ dikatakan Berhasil.

\section{Data dan Sumber Data}

Data penelitian terdiri atas (1) data pemantau tindakan (action) yang merupakan data yang digunakan untuk mengontrol kesesuaian tindakan dengan rencana dengan proses aktivitas Mahasiswa PGSD FIP UNJ dalam memahami konsep asesmen melalui strategi mind mapping dan (2) data penelitian (research) merupakan data yang tampak dari tindakan yang diberikan yaitu data tentang pemahaman konsep asesmen mahasiswa melalui strategi mind mapping.

Teknik Pengumpulan Data dan Instrumen yang Digunakan

Teknik pengumpulan data dilakukan dengan cara (1) observasi, (2) lembar pengamatan yang dilakukan oleh subyek/partisipan yang terlibat dalam penelitian, (3) dokumentasi, dan (4) catatan lapangan, penilaian produk. Instrumen yang digunakan berbentuk format/pedoman pengamatan pelaksanaan tindakan kelas, catatan lapangan. Dan berbentuk 
proses serta hasil pengamatan penilaian produk mind mapping yang dibuat mahasiswa sesuai dengan kriteria atau pencapaian indikator yang telah ditetapkan oleh peneliti.

\section{Analisis Data dan Interpretasi Hasil Analisis}

Analisis data dilakukan peneliti dan kolaborator pada setiap kegiatan refleksi dalam satu siklus untuk mendapatkan gambaran yang sesuai antara tindakan yang diberikan dengan rencana yang telah disusun dan menemukan kekurangan dan kelebihannya. Hasil analisis data siklus I dijadikan acuan perencanaan pada siklus berikutnya sampai terjadi peningkatan aktivitas belajar, maka peneliti dan kolaborator menetapkan penelitian telah selesai. Sedangkan interpretasi hasil analisis berupa analisis aktivitas mahasiswa dalam memahami konsep asesmen melalui strategi mind mapping.

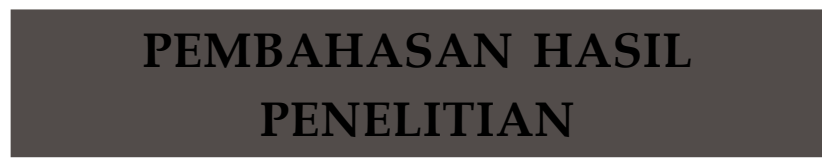

\section{Perencanaan}

Perkuliahan dirancang dengan membagi kelas menjadi 6 kelompok lebih dahulu, yaitu: kelompok klas 1, klas 2, klas 3, klas 4, klas 5, dan klas 6. Setiap kelompok memahami Standar Kompetensi (SK)/Kompetensi Dasar (KD) dalam kurikulum di setiap kelasnya. Kemudian membuat instrumen penelitian tentang pemahaman konsep asesmen mahasiswa dan panduan pelaksanaan perkuliahan Pengembangan Evaluasi Pembelajaran menggunakan strategi mind mapping, menyiapkan media rekam gambar.

\section{Pelaksanaan}

Perkuliahan pengembangan evaluasi pembelajaran dengan strategi mind mapping ditandai dengan kerja setiap kelompok (kelompok klas 1 sampai klas 6).

\section{Pertemuan pertama:}

Setiap kelompok melakukan analisis terhadap kurikulum Matematika, dilihat dari indikator yang sudah dibuat di sekolah masing-masing berdasarkan SK/KD

Masing-masing kelompok melakukan analisis terhadap kurikulum (KTSP) sesuai dengan kelompok masing-masing. Kelompok 1 menganalisis kurikulum Matematika klas 1, kelompok 2 menganalisis kurikulum klas 2, dan seterusnya.

Pertemuan kedua:

Pada pertemuan kedua, setiap kelompok mulai memetakkan (berdasarkan kesepakatan dari hasil alur pikir masing-masing anggota) indikatorindikator yang saling berhubungan untuk digabungkan ke dalam satu peta konsep dan dimasukkan dalam satu jenis penilaian yang sesuai serta menggunakan strategi mind mapping.

Pertemuan ketiga:

Setiap kelompok membuat rancangan jenis penilaian yang sudah dipilih, hasil kerja dari masingmasing kelompok adalah sebagai berikut:

Siklus pertama:

\begin{tabular}{|c|c|c|c|c|c|c|}
\hline No & Absensi & Tugas & UTS & UAS & $\begin{array}{l}\text { Nilai } \\
\text { Akhir }\end{array}$ & \\
\hline 1 & 100 & 35 & 85 & 42.5 & 58.38 & \\
\hline 2 & 100 & 72 & 85 & 47.5 & 72.58 & 1 \\
\hline 3 & 90 & 62 & 75 & 25 & 59.45 & \\
\hline 4 & 90 & 65 & 85 & 25 & 63.50 & \\
\hline 5 & 90 & 62 & 80 & 42.5 & 65.33 & \\
\hline 6 & 100 & 83 & 90 & 45 & 77.30 & 2 \\
\hline 7 & 100 & 38 & 85 & 67.5 & 65.68 & \\
\hline 8 & 100 & 73 & 90 & 47.5 & 74.43 & 3 \\
\hline 9 & 100 & 73 & 90 & 47.5 & 74.43 & 4 \\
\hline 10 & 100 & 63 & 70 & 17.5 & 57.43 & \\
\hline 11 & 90 & 73 & 90 & 47.5 & 73.43 & 5 \\
\hline 12 & 90 & 28 & 80 & 37.5 & 52.18 & \\
\hline 13 & 90 & 43 & 90 & 47.5 & 62.93 & \\
\hline 14 & 100 & 45 & 85 & 37.5 & 60.63 & \\
\hline 15 & 80 & 63 & 80 & 32.5 & 62.18 & \\
\hline 16 & 100 & 72 & 85 & 47.5 & 72.58 & 6 \\
\hline 17 & 60 & 63 & 75 & 45 & 61.80 & \\
\hline 18 & 90 & 60 & 90 & 35 & 65.75 & \\
\hline 19 & 100 & 38 & 85 & 42.5 & 59.43 & \\
\hline 20 & 90 & 62 & 90 & 42.5 & 68.33 & \\
\hline 21 & 90 & 38 & 75 & 52.5 & 57.93 & \\
\hline 22 & 80 & 60 & 80 & 37.5 & 62.38 & \\
\hline 23 & 80 & 67 & 85 & 67.5 & 73.83 & 7 \\
\hline 24 & 100 & 62 & 70 & 45 & 63.95 & \\
\hline 25 & 100 & 50 & 90 & 52.5 & 67.63 & \\
\hline 26 & 100 & 60 & 80 & 45 & 66.25 & \\
\hline 27 & 100 & 62 & 85 & 70 & 74.70 & 8 \\
\hline 28 & 100 & 63 & 90 & 52.5 & 72.18 & 9 \\
\hline 29 & 90 & 20 & 75 & 42.5 & 49.13 & \\
\hline 30 & 100 & 60 & 85 & 45 & 67.75 & \\
\hline
\end{tabular}

Sedangkan hasil penilaian peneliti terhadap kerja kelompok tentang pemahaman konsep asesmen Mahasiswa PGSD FIP UNJ adalah.

\begin{tabular}{|c|l|c|}
\hline $\begin{array}{c}\text { No } \\
\text { Butir }\end{array}$ & \multicolumn{1}{|c|}{$\begin{array}{c}\text { Aspek yang } \\
\text { diukur }\end{array}$} & $\begin{array}{c}\text { Skor rata-rata } \\
\text { kelompok }\end{array}$ \\
\hline 1 & $\begin{array}{l}\text { Mengenal jenis-jenis } \\
\text { penilaian }\end{array}$ & 10 \\
\hline 2 & $\begin{array}{l}\text { Menyebutkan fungsi } \\
\text { dan kegunaan jenis- } \\
\text { jenis penilaian }\end{array}$ & 15 \\
\hline 3 & $\begin{array}{l}\text { Memetakan materi } \\
\text { untuk menentukan } \\
\text { jenis penilaian yang } \\
\text { sesuai }\end{array}$ & 20 \\
\hline 4 & $\begin{array}{l}\text { Membuat rancangan } \\
\text { penilaian } \\
\text { Membuat instrumen } \\
\text { penilaian berdasarkan } \\
\text { materi dan jenis } \\
\text { penilaian yang sesuai }\end{array}$ & 20 \\
\hline 5 & \begin{tabular}{l} 
Skor perolehan \\
\hline
\end{tabular}
\end{tabular}




\section{Refleksi}

Dari hasil evaluasi, baik dalam bentuk tes maupun non tes dapat dinyatakan bahwa: jumlah siswa yang mendapatkan skor minimal 70 hanya 9 $(30 \%)$ orang. Ini berarti masih belum memenuhi indikator keberhasilan yang ditentukan. Hal itu didukung juga dengan pemahaman konsep asesmen yang diukur dengan instrumen non tes menunjukkan skor rata-rata kelompok adalah 73.

Dari hasil evaluasi yang diperoleh tersebut, peneliti bersama-sama dengan observer dan mahasiswa berdiskusi untuk melakukan perencanaan ulang, yaitu dengan menitikberatkan pada penemuan observer, untuk memperbaiki aspek-aspek pada instrumen pemantau tindakan yang masih kurang, dan peneliti sebagai dosen berdiskusi dengan mahasiswa untuk membetulkan hasil kerjaan yang telah dilakukan.

\section{Siklus 2}

Setelah dilakukan perencanaan ulang, kemudian mahasiswa mulai bekerja lagi dengan cara membetulkan hasil kerjaannya, baik secara individu maupun kelompok. Hasil yang diperoleh pada siklus 2 adalah sebagai berikut:

\section{Hasil Evaluasi Bentuk Tes}

\begin{tabular}{|c|c|c|c|c|c|c|}
\hline No & Absensi & Tugas & UTS & UAS & $\begin{array}{l}\text { Nilai } \\
\text { Akhir }\end{array}$ & \\
\hline 1 & 90 & 85 & 75 & 45 & 72.50 & 1 \\
\hline 2 & 100 & 80 & 70 & 55 & 72.75 & 2 \\
\hline 3 & 100 & 85 & 90 & 70 & 84.25 & 3 \\
\hline 4 & 100 & 80 & 90 & 65 & 81.25 & 4 \\
\hline 5 & 80 & 80 & 75 & 70 & 76.00 & 5 \\
\hline 6 & 100 & 85 & 80 & 77.5 & 83.13 & 6 \\
\hline 7 & 100 & 85 & 90 & 87.5 & 88.63 & 7 \\
\hline 8 & 80 & 80 & 75 & 87.5 & 80.38 & 8 \\
\hline 9 & 90 & 80 & 90 & 60 & 79.00 & 9 \\
\hline 10 & 100 & 80 & 85 & 57.5 & 77.88 & 10 \\
\hline 11 & 100 & 80 & 90 & 77.5 & 84.38 & 11 \\
\hline 12 & 100 & 85 & 80 & 45 & 75.00 & 12 \\
\hline 13 & 100 & 80 & 85 & 55 & 77.25 & 13 \\
\hline 14 & 100 & 80 & 95 & 92.5 & 89.63 & 14 \\
\hline 15 & 100 & 80 & 85 & 50 & 76.00 & 15 \\
\hline 16 & 90 & 80 & 85 & 42.5 & 73.13 & 16 \\
\hline 17 & 100 & 85 & 80 & 80 & 83.75 & 17 \\
\hline 18 & 100 & 80 & 75 & 75 & 79.25 & 18 \\
\hline 19 & 100 & 80 & 70 & 80 & 79.00 & 19 \\
\hline 20 & 100 & 80 & 90 & 77.5 & 84.38 & 20 \\
\hline 21 & 100 & 80 & 80 & 77.5 & 81.38 & 21 \\
\hline 22 & 100 & 80 & 70 & 60 & 74.00 & 22 \\
\hline 23 & 100 & 70 & 75 & 60 & 72.00 & 23 \\
\hline 24 & 80 & 80 & 75 & 52.5 & 71.63 & 24 \\
\hline 25 & 100 & 85 & 80 & 70 & 81.25 & 25 \\
\hline 26 & 100 & 80 & 90 & 61.5 & 80.38 & 26 \\
\hline 27 & 100 & 80 & 75 & 37.5 & 69.88 & \\
\hline 28 & 100 & 85 & 70 & 52.5 & 73.88 & 27 \\
\hline 29 & 100 & 80 & 75 & 75 & 79.25 & 28 \\
\hline 30 & 90 & 85 & 70 & 67.5 & 76.63 & 29 \\
\hline
\end{tabular}

\section{Hasil Evaluasi bentuk Non Tes}

\begin{tabular}{|c|c|c|}
\hline $\begin{array}{l}\text { No } \\
\text { Butir }\end{array}$ & $\begin{array}{c}\text { Aspek yang } \\
\text { diukur }\end{array}$ & $\begin{array}{c}\text { Skor rata-rata } \\
\text { kelompok }\end{array}$ \\
\hline 1 & $\begin{array}{l}\text { Mengenal jenis-jenis } \\
\text { penilaian }\end{array}$ & 10 \\
\hline 2 & $\begin{array}{l}\text { Menyebutkan fungsi } \\
\text { dan kegunaan jenis- } \\
\text { jenis penilaian }\end{array}$ & 6 \\
\hline 3 & $\begin{array}{l}\text { Memetakan materi } \\
\text { untuk menentukan } \\
\text { jenis penilaian yang } \\
\text { sesuai }\end{array}$ & 15 \\
\hline 4 & $\begin{array}{l}\text { Membuat rancangan } \\
\text { penilaian }\end{array}$ & 20 \\
\hline 5 & $\begin{array}{l}\text { Membuat instrumen } \\
\text { penilaian } \\
\text { berdasarkan materi } \\
\text { dan jenis penilaian } \\
\text { yang sesuai }\end{array}$ & 20 \\
\hline \multicolumn{2}{|r|}{ gerolehan } & 71 \\
\hline
\end{tabular}

Dari hasil evaluasi, baik dalam bentuk tes maupun non tes dapat dinyatakan bahwa: jumlah siswa yang mendapatkan skor 70 keatas adalah 29 orang atau $96 \%$, ini berarti sudah memenuhi indikator keberhasilan yang ditentukan. Hal itu didukung juga dengan pemahaman konsep asesmen yang diukur dengan instrumen non tes menunjukkan skor rata-rata kelompok adalah 84 .

\section{Pembahasan Hasil Penelitian}

Dosen dalam proses perkuliahan diharapkan selalu mengadakan interaksi dengan mahasiswa, dosen menyampaikan informasi berkenaan dengan materi perkuliahan yang sudah dituliskan dalam silabus, sedangkan mahasiswa akan mengkonstruksinya dengan cara menerima, mencari tambahan informasi dari berbagai sumber, mengolah dan menggunakan materi yang diberikan dosen. Keberhasilan mahasiswa selain dipengaruhi oleh cara dosen melaksanakan proses pembelajaran dan cara mahasiswa belajar (menyerap dan mengolah informasi), juga ditentukan oleh model penilaian (asesmen) yang dipilih dosen setelah pembuatan satuan acara perkuliahan.

Dari hasil penelitian sebanyak dua siklus terbukti para mahasiswa sudah dapat menguasai dan memahami konsep asesmen, secara detil bahasan hasil penelitian adalah sebagai berikut:

Pada siklus 1 (satu), perolehan hasil evaluasi, baik dalam bentuk tes maupun non tes dapat dinyatakan bahwa: jumlah siswa yang mendapatkan skor minimal 70 pada saat penilaian individu dengan alat ukut tes hanya sebanyak 9 orang atau hanya 30\% dari jumlah seluruh kelas, ini berarti para Mahasiswa belum paham sekali cara menerapkan strategi mind mapping. Hal itu didukung juga dengan pemahaman konsep asesmen yang diukur dengan instrumen non 
tes tentang pemahaman Mahasiswa terhadap konsep asesmen menunjukkan skor rata-rata tiap kelompok adalah 73 .

Setelah peneliti bersama-sama dengan observer dan mahasiswa berdiskusi, ternyata Mahasiswa belum mengerti dan mengenal fungsi dan kegunaan masing-masing jenis-jenis penilaian, ini mengakibatkan cara memetakan materi untuk menentukan jenis penilaian yang sesuai juga salah dan rancangan yang dibuatnyapun tidak benar, dan berakibat dalam membuat instrumen penilaian berdasarkan materi dan jenis penilaian tidak sesuai

Untuk itu peneliti melakukan perencanaan ulang dengan menjelaskan kembali dan berdiskusi dengan mahasiswa mengulang materi dan dengan menitik beratkan pada aspek-aspek pada instrumen pemantau tindakan yang masih kurang

Setelah dilakukan perbaikan, maka perolehan hasil evaluasi, baik dalam bentuk tes maupun non tes dapat dinyatakan bahwa: jumlah siswa yang mendapatkan skor 70 keatas adalah 29 orang atau $96 \%$, ini berarti sudah memenuhi indikator keberhasilan yang ditentukan. Hal itu didukung juga dengan pemahaman konsep asesmen yang diukur dengan instrumen non tes menunjukkan skor rata-rata kelompok adalah 84 .

\section{PENUTUP}

\section{Kesimpulan}

Metode Pengembangan dan Peningkatan Kualitas Pembelajaran (PPKP) di LPTK melalui pendekatan penelitian tindakan kelas (PTK) memiliki tujuan untuk melakukan perbaikan terhadap proses perkuliahan, penelitian dilakukan masing-masing individu dalam suatu kelompok, dengan model siklus, dimana pada setiap siklusnya terdiri dari tahapan: perencanaan, pelaksanaan, observasi, dan refleksi.

Dari hasil penelitian baik yang berbentuk evaluasi bentuk tes dan non tes ternyata dapat diketahui bahwa, pemahaman konsep asesmen mahasiswa PGSD FIP UNJ setelah diterapkankan strategi mind mapping pada perkuliahan pengembangan evaluasi pembelajaran terbukti dapat ditingkatkan

\section{Saran}

Dari kesimpulan yang diuraikan di atas, maka peneliti menyarankan kepada:

1. Dosen pengampu mata kuliah evaluasi, untuk mencobakan strategi mind mapping pada saat mengajar

2. Mahasiswa sebagai guru, untuk menggunakan strategi mind mapping pada saat akan melaksanakan kegiatan penilaian.

3. Mahasiswa sebagai calon guru, untuk mencoba strategi mind mapping pada saat akan menentukan jenis evaluasi yang akan digunakan baik untuk tugas-tugas mata kuliah maupun jika mengajar nanti.

4. Pembaca yang peduli terhadap penilaian bagi peserta didik, untuk memperhatikan strategi ini sebagai salah satu acuan bahwa berhasilnya suatu pembelajaran juga sangat bergantung pada cara penilaian yang diambil guru.

\section{DAFTAR PUSTAKA}

Amaliah, Nurul., (2006). Perbedaan model pembelajaran mind mapping dengan pembelajaran konvensional terhadap hasil belajr siswa pada program diklat teknik analog.

Anon, 2003. Kurikulum berbasis kompetensi. Jakarta: Depdiknas.

2005. Peningkatan kualitas pembelajaran. Jakarta: Depdiknas.

------,2006. Kurikulum PGSD FIP UN, Jakarta: Depdiknas.

Http:/ / digilib.upi.edu / pasca / available/ etd0911106-120306. Diakses pada tanggal 18 Juli 2007.

\section{KETERANGAN PENULIS}

Dra. Siti Rohmi Yuliati, M. Pd, lahir di Solo pada tanggal 16 Juli 1957. Saat ini masih menjabat sebagai dosen PGSD FIP UNJ. 